\title{
О СОСТАВЕ УГЛЕВОДОРОДОВ РЯДА ИНДАНА И ТЕТРАЛИНА ЭСТОНСКОГО СЛАНЦЕВОГО БЕНЗИНА
}

\author{
О. ЭИЗЕН,
}

\section{кандидат технических наук}

При термической переработке горючего сланца процессы разложения керогена протекают в конечном результате пренмущественно с образованнем в составе сланце. вого бензина нормальных парафиновых и олефиновых углеводородов от $\mathrm{C}_{5}$ до $\mathrm{C}_{10}\left[{ }^{1}\right]$. Содержанис ароматических углеводородов в бензиновых фракциях, получаемых при низкотемпературной обработке сланца, значительно ниже и колеблется в пределах $8-15 \%$.

В ходе нсследования химического состава сланцевой смолы количественно идентифицированы ароматические углеводороды от $\mathrm{C}_{6}$ до $\mathrm{C}_{8}\left[{ }^{4}, 5\right]$, в то время как данные об ароматических углеводородах, содержащихся в более высококипящих фракциях, носят почти без исключения качественный характер $\left[{ }^{6}, 7^{7}, 8\right]$. Вообще не проработана фракция $150-215^{\circ}$, в состав которой входят ароматические углеводороды $\mathrm{C}_{9}-\mathrm{C}_{11}$. Некоторые из указанных углеводородов рассмотрены в работах Давтяна и Вьюновой [9, $\left.{ }^{10}\right]$, посвященных исследованню соединений, образовавшихся либо в результате термического растворения сланца, либо при крекинге сланцевой смолы. Присутствие индивидуальных индановых соединений в сланцевой смоле до настоящего времени не доказано.

За последние годы проведено ряд работ, доказываюших присутствие индана и его гомологов в средних фракциях нефти. [2, $\left.{ }^{3}\right]$.

Автору настоящей статьи впервые удалось идентифицировать некоторые нндано вые углеводороды в эстонской сланцевой смоле, данные о которых излагаются ниже.

В качестве исходного материала использовалась фракция $150-210^{\circ}$, выделенная посредством ректификации из пропорциональной смеси газбензина, печного бензина и легкого масла, полученных в результате полукоксования сланца в туннельных печах сланцехимического комбината «Кивиыли».

Помимо указанной смеси, индан был определен в бензинах камерных печей, установки с твердым теплоносителем и шахтных генерагоров.

Фракция $150-210^{\circ}$ дефенолировалась и разделялась хроматографированием на силикагеле по элюентному методу на парафиновые, олефиновые и ароматические углеводороды и кислородные соединения.

Концентраты ароматических углеводородов дистиллировались на фракции в колонке с разделяющей способностью в 40 теоретических тарелок в вакууме при остаточном давлении 100 мм рт. ст. Результаты дистилляции ароматических углеводородов и физико-химическая характеристика полученных фракций приведены на рис. 1.

Из данных рис. 1 следует, что соединения, обладающие более высоким показателем преломления, сконцентрировались во фракциях со следующими пределами кипения: $172-180,186-189,210-220^{\circ}$.

С учетом указанных в литературе [12] температур кипения, из индивидуальных соединений ряда индана во фракции $172-182^{\circ}$ могут встречаться индан и инден, а во фракции $186-189^{\circ}-1$-метилиндан и 2-метилиндан, в то время как в пределах кипения $201-207^{\circ}$ и $210-220^{\circ}$ число возможных соединений уже относительно высокое

В данном случае представляется наиболее целесообразным осуществлять идентификацию и количественное определение этих соединений при помощи инфракрасной спектроскопни и газохроматографни. Точность инфракрасного спектрального ана- 


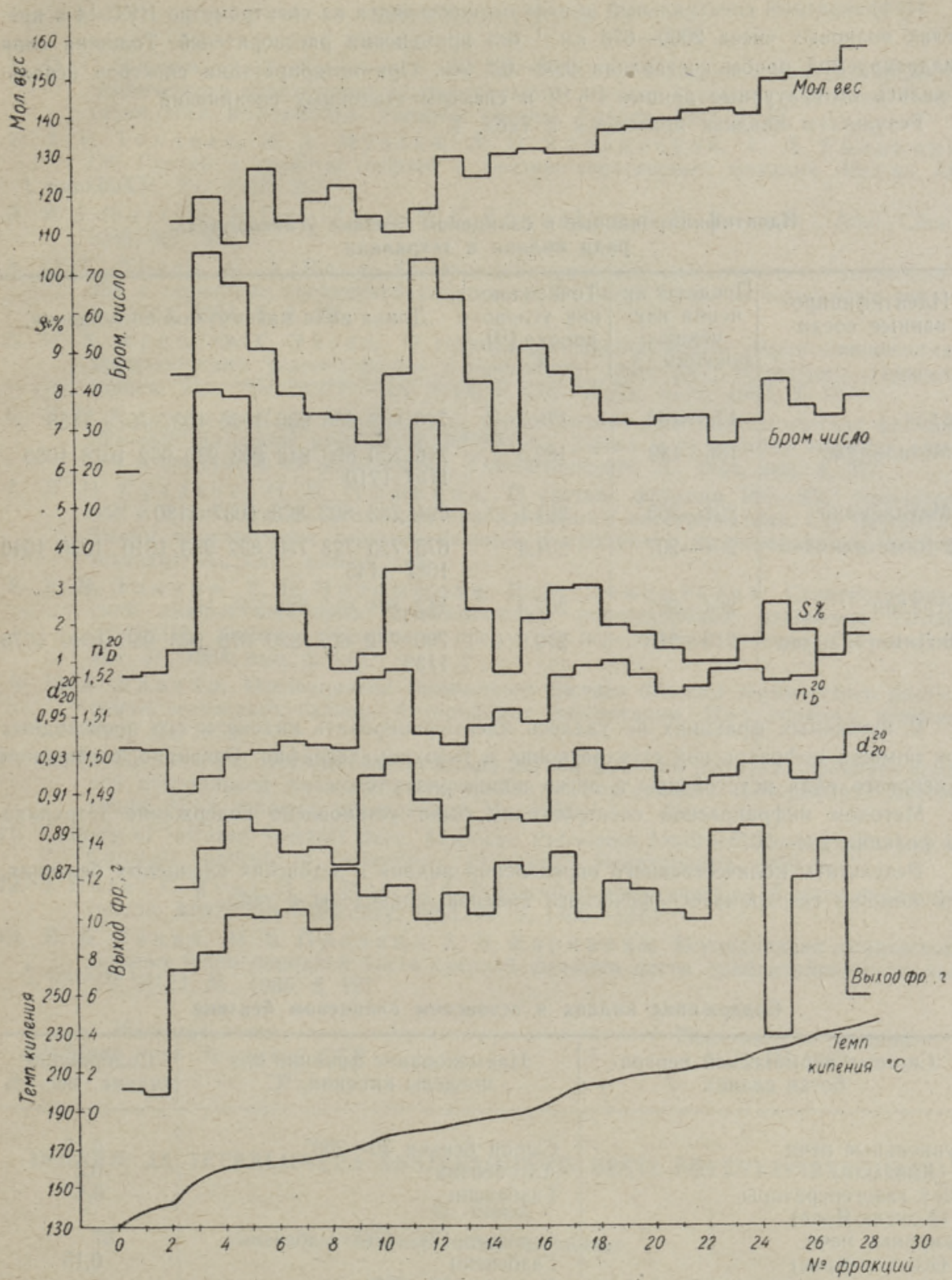

Рис. 1. Физико-химическая характеристика узких фракций ароматических углеводородов сланцевого бензина.

лиза соединений инданового ряда вполне удовлетворительна, так как спектры этих соединений имеют в пределе волновых чисел 1000-690 см-1 ряд характерных абсорбционных максимумов.

Газохроматография была проведена на хроматографе, сконструированном в Институте химии АН ЭССР. При проведении анализа применялись $3-7$-метровые колонки (Ø 6 мм), наполненные полигликолем 4000 (фирма Мерк) и $\beta, \beta^{\prime}$-тиодипропионитрилом на диатомите. 
Инфракрасный спектральный анализ ссуществлялся на спектрометре ИКС-14 в пределах волновых чнсел 2000-675 $\mathrm{cm}^{-1}$ без применения растворителей. Толщина слоя анализируемой пробы составляла 0,03-0,2 мм. При интерпретации спектров нспользовались литературные данные $\left[{ }^{11},{ }^{12}\right]$ и спектры эталонных соединенин.

Результаты анализа приведены в табл. 1.

Таблица $f$

\section{Идентифицированные в сланцевом бензине углеводороды ряда индана и тетралнна}

\begin{tabular}{|c|c|c|c|}
\hline $\begin{array}{c}\text { Идентифициро- } \\
\text { ванные соеди- } \\
\text { нения }\end{array}$ & $\left|\begin{array}{c}\text { Пределы ки- } \\
\text { пения изу- } \\
\text { ченных } \\
\text { фракший, }{ }^{\circ} \mathrm{C}\end{array}\right|$ & $\begin{array}{l}\text { Точка кипе- } \\
\text { ния углево- } \\
\text { дорода }\left[{ }^{12}\right] \text {, } \\
{ }^{\circ} \mathrm{C}\end{array}$ & $\begin{array}{l}\text { Длина волн макснмумов поглошения, } \\
\qquad \mathrm{CM}^{-1}\end{array}$ \\
\hline Индан & $178-180$ & 176,7 & $\begin{array}{llllllll}740 & 833 & 855 & 930 & 1025 & 1037 & 1079 & 1158\end{array}$ \\
\hline 1-Метилиндан & $186-189$ & 189,5 & 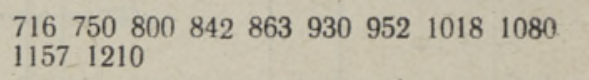 \\
\hline 5-Метилиндан & $201-203$ & 201,1 & $\begin{array}{llllll}694 & 763 & 803 & 863 & 1037 & 1130\end{array}$ \\
\hline 1,2-Диметилиндан & $204-207$ & 204,8 & $\begin{array}{llllllll}675720 & 723 & 750 & 802 & 933 & 1010 & 1020 & 1040 \\
1087 & 1145\end{array}$ \\
\hline Тетралин & $204-207$ & 207,4 & 7428048658989461110 \\
\hline 1,6-Диметилиндан & $210-215$ & 210,9 & $\begin{array}{lllllllll}700 & 772 & 807 & 820 & 875 & 903 & 950 & 1040 & 1075 \\
1133 & & & & & & & & \end{array}$ \\
\hline
\end{tabular}

В изучаемых фракциях не удалось идентифицировать индена и его производных при помощи инфракрасной спектроскопии и газохроматографии. Очевидно, соединения ннденового ряда неустойчивы и легко полимеризуются.

Методом инфракрасной спектроскопии было установлено содержание тетралина во фракции $204-207^{\circ}$.

Результаты количественного определения индана в эстонских сланцевых бензинах, при помощи газохроматографнческого анализа, приведены в табл. 2.

Tаблица 2

\section{Содержание индана в эстонском сланцевом бензине}

\begin{tabular}{|c|c|c|}
\hline $\begin{array}{c}\text { Система термической перера- } \\
\text { ботки сланца }\end{array}$ & $\begin{array}{c}\text { Наименование фракции или } \\
\text { пределы кипения, }{ }^{\circ} \mathrm{C}\end{array}$ & $\begin{array}{c}\text { Содержанне } \\
\text { индана, вес. \% }\end{array}$ \\
\hline $\begin{array}{l}\text { Туннельные печи } \\
\text { (Кивиыли) } \\
\text { 125-т газогенераторы } \\
\text { (Кохтла-Ярве) } \\
\text { Камерные печи } \\
\text { (Кохтла-Ярве) } \\
\text { Установка с твердым теплоно- } \\
\text { сителем (Кивиыли) } \\
\text { Установка с твердым теплоно- } \\
\text { сителем (Кивиыли) }\end{array}$ & $\begin{array}{l}\text { Сырой бензин } 30-200^{\circ} \\
\text { Автобензин } \\
\text { Газбензин } \\
\text { Фракция } 174-176^{\circ} \text { газбензина } \\
\text { Газбензин } \\
\text { Фракция } 30-200^{\circ} \\
\text { Температура в реакторе } 500^{\circ} \\
\text { Фракция } 30-200^{\circ} \\
\text { Температура в реакторе } 530^{\circ}\end{array}$ & $\begin{array}{l}0,15 \\
0,2 \\
0,4 \\
67 \\
0,15 \\
0,4 \\
0,5\end{array}$ \\
\hline
\end{tabular}

На основании приведенных в настоящей статье данных доказано наличие в эстонской сланцевой смоле углеводородов ряда индана и тетралина.

При этом следует обратить внимание на то, что по сравнению с инданом тетралин встречается в меньшем количестве. Это согласуется с данными более ранних исследований $\left[{ }^{13}\right]$, показывающими, что и в случае нафтеновых углеводородов в „средних фракциях сланцевой смолы преобладают пятичленные циклы. 


\title{
Л ИТЕ РАТУ РА
}

1. О. Г. Эйзен, Э. Х. А р уме л, Ю. И. Э йзен, Экспресс-метод газохроматографического определения индивидуального состава сланцевого бензина. Бюлл. научн.-техн. информацин. Горючие сланцы, Таллин, 1962, 2, 42.

2. А. В. Топчиев, И. А.. Мусаев, А. Н. Кислинский, Г. Д. Г альперн, Сб. Состав и свойства нефтей и бензино-керосиновых фракций. Изд-во АН CCCP, M., 1957, 253.

3. B. J. Mair, Sh. P. D a vidson, N. C. Kronskop, F. D. Rossini, Anal. Chem., $1958,30,1814$.

4. О. Г. Эй зен, С. А. Р ан г, О химическом составе ароматических углеводородов и сернистых соединений сланцевого бензина. Химия и технология топлив и масел, $1961,6,6,29$.

5. И. Х. А р ро, О. Г. Эйзен, О спектрально-аналитическом определении легких ароматических углеводородов в продуктах перегонки эстонского горючего сланца, Изв. АН ЭССР. Сер. техн. и фнз.-матем. наук, 1960, 3, 187.

6. Л. Н. Г ул я в а, Н. Н. П ы ки н а, Исследование химического состава фракции $180-330^{\circ}$ камерной смолы. Сб. ВНИИПС. Химия и технология горючих сланцев и продуктов их переработки. Гостоптехиздат, Л., 1956, вын. 5, 217.

7. Л. Н. Гуляев а, Н. И. П ышкин а, О составе фракции $180-330^{\circ}$ генераторной и туннельной смол сланцев прибалтийского месторождения. Сб. ВНИИПС Химия и технология горючих сланщев и продуктов их переработки. Гостоптехиздат, Л., 1955, вып. 4, 145.

8. 'Е. И. Т омина, К. Б. Ч ернышева, Е. М. Д ем ен тьев а, Спектрографический анализ некоторых ароматических углеводородов сланцевой смолы. ВНИИПС. Химия и технология продуктов переработки сланцев. Гостоптехиздат, Л., 1954, вып. 2, 145.

9. Н. А. Д а в т ян, Исследование химического состава бензина термического растворения эстонского сланца. Автореферат диссертации. Ин-т горючих ископаемых, M., 1952.

10. Н, Г. В ьюн о в а, Исследование состава легкой фракции продукта крекинга средней нейтральной фракции дегтя прибалтийских сланцев. Автореферат диссертации. Ин-т горючих ископаемых. М., 1952.

11. Catalog of Infrared Spectral Data. American Petroleum Institute. Research Project 44. Carnegie Institute of Technology. Pittsburgh, Pennsylvania, 1959.

12. I. Ente l, C. R u o f, H. C. How a r d, Preparation and properties of some methylated indans. Analytical Chemistry, 1953, 25, 9, 1303-1310.

13. В. А. Л а н ин, М. В. П ронин а, А. В. К а рн а в а, Исследование химического состава углеводородной части средней фракции дегтя прибалтийского сланца. Тр. ИГИ, М., 1955, 5, 127.

\author{
Ннститут химии \\ Ннститут химии
Академии наук Эстонской ССР \\ Поступила в редакцию \\ 8. IV 1963
}

\section{INDAAN- JA TETRALIINREA SUSIVESINIKUD EESTI POLLEVKIVIBENSIINIS}

\author{
o. Eisen, \\ tehnikateaduste kandidaat
}

Resümee

Eesti pōlevkivibensiinis eraldati silikageelil kromatografeerimisega aromaatsed süsivesinikud. Nende kontsentraat rektifitseeriti kitsasteks fraktsioonideks, milles esmakordselt identifitseeriti infrapunase spektraalanalüüsiga indaan, 1-metüülindaan, 5-metüülindaan, tetraliin ja 1,6-dimetüülindaan. Gaasikromatograafiliselt määrati indaani kogus mitmesugustes pôlevkivi vedelproduktides. 


\section{BESTIMMUNG VON INDAN- UND TETRALIN-KOHLENWASSERSTOFFEN IM ESTNISCHEN BRENNSCHIEFERBENZIN}

\section{o. Eisen}

\section{Zusammenfassung}

Aus dem Brennschieferbenzin wurden die aromatischen Kohlenwasserstoffe durch Chromatographie auf Silikagel getrennt. Das Konzentrat der aromatischen Kohlenwasserstoffe wurde zu engen Fraktionen rektifiziert. Mit Hilfe von Ultrarotspektroskopie wurden in der Benzinfraktion $150-215^{\circ} \mathrm{C}$ der Tunnelöfen von Kiviöli zum ersten mal Indan, 1-Methylindan, 5-Methylindan, Tetralin und 1,6-Dimethylindan qualitativ identifiziert. Gaschromatographische Bestimmung von Indan wurde bei einigen Brennschieferbenzinen durchgeführt.

$$
\text { Institut für Chemie }
$$

